\title{
HUMAN HEALTH RISK ASSESSMENT OF AIRBORNE TRACE ELEMENTS FOR HUMAN RECEPTORS IN THE VICINITY OF THE DIAMOND CEMENT FACTORY, VOLTA REGION, GHANA
}

\author{
M.A. ADDO ${ }^{1}$, E.O. DARKO ${ }^{1}$, C. GORDON ${ }^{2}$, P. DAVOR ${ }^{1}$, F. AMEYAW ${ }^{1}$, H. AFFUM ${ }^{1}$, \\ J.K. GBADAGO ${ }^{1}$, \& S. DZIDE ${ }^{1}$ \\ ${ }^{1}$ Ghana Atomic Energy Commission, Ghana \\ ${ }^{2}$ University of Ghana, Ghana
}

\begin{abstract}
In this study, total suspended particulate matter (aerodynamic diameter range between 0.05 and $5 \mu \mathrm{m}$ ) levels in the vicinity of the Diamond Cement (DIACEM) Factory, Aflao, Ghana were measured and analyzed for $\mathrm{As}, \mathrm{Cr}, \mathrm{Ni}$ and $\mathrm{Zn}$ using multi-elemental technique of instrumental neutron-activation analysis. The primary objective of the study was to assess the human health risk of the trace metals exposure for children and adult population in four stratified zones in the study area. From the results, the mean dust level $\left(538.92 \mu \mathrm{g} / \mathrm{m}^{3}\right)$ around the cement facility deviated completely from regulatory specification $\left(150 \mu \mathrm{g} / \mathrm{m}^{3}\right)$ indicating massive air pollution in the area. The mean concentration $(\mathrm{mg} / \mathrm{kg})$ of trace metals in the area were found in the order of $\mathrm{Ni}(44.38)>\mathrm{Zn}(25.65)>\mathrm{Cr}$ (15.26) >As (2.87). The human-risk assessment study indicated that non-carcinogenic risk was insignificant but the risk of cancer could be probable. Ingestion exposure was the highest level of risk found for both adults and children population in the area. The study encourages more work as it cautioned that the current results cannot symbolize a general portrait of the cement industry in Ghana, explaining that similar facilities may differ in their pollution cleaning strategies and environmental conditions.

Keywords: airborne dust, arsenic, carcinogenic, cement industry, enrichment factor, hazard index, ingestion, risk assessment, slope factor, trace metals.
\end{abstract}

\section{INTRODUCTION}

Industrialization is highly desirable for the sustenance of a nation's economy and the enhancement of the citizenry's well-being [1]. The advent of the industrial revolution has considered economic performance as the principal criteria for measuring progress [2]. However, the industrial events have been accompanied by negative growing impacts on the environment that can sometimes be catastrophic.

Evidently, industries that employ thermal processes, such as, gold processing, fossil fuel combustion and cement manufacturing release enormous pollutants into the atmosphere. Cement is manufactured through a series of processes that include the mining, crushing and grinding of raw materials, blending and kiln burning to form clinker (calcining), cement milling and packaging [3]. Dust is emitted during these processes exposing the ambient air to total suspended particulate matter. Portland cement dust is a gray powder with an aerodynamic diameter ranging from 0.05 to $5 \mu \mathrm{m}$ [4]. Atmospheric pollutants emitted during cement manufacture include heavy metals ( $\mathrm{As}, \mathrm{Cd}, \mathrm{Cr}, \mathrm{Hg}, \mathrm{Ni}, \mathrm{Pb}, \mathrm{Zn}$ etc.) and groups of organic substances (polychlorinated dibenzo-p-dioxin and dibenzofurans) $[4,5]$. 
The aerodynamic size of cement dust particles allow them to spread along large areas through wind, rain and so on. They are accumulated in soils, plants and animals and can affect human health adversely [6].

Several studies in the cement industry have tended to link the effect of cement dust exposure in humans to the respiratory system [2,7]. However, evidence from other studies on experimental animals suggests that cement dust may deleteriously affect other systems as well. For instance, the cement industry has the highest number of reported cases of dermatitis and conjunctivitis in Nigeria [8] suggesting that cement dust affects the skin and the eyes as well.

The pollutants from cement may affect public health directly because of the greater probability of contact with the suspended dust [9]. Toxic impurities of dust have different routes of exposure to the human system [10]. The exposure rout pathways include inhalation through the respiratory system, ingestion by virtue of food or water intake and dermal contact with the skin.

Excessive accumulation of trace metals in human bodies creates problems like cardiovascular, kidney, nervous and bone diseases [11]. For instance, metals like arsenic (As) has been associated with various systemic effects like cardiovascular diseases, skin disorders and neurotoxicity. These health concerns become of greater issue when we consider susceptible populations such as young children living close to these industrial emission sources.

The current study focuses on the Diamond Cement (DIACEM) Factory in the Volta Region of Ghana which has been in operation since 2002. Of recent, public concerns over adverse health effects for the population surrounding the facility has increased. The social impact of the plant has been a subject of much controversy since farming occupation has also been greatly disturbed. The most disturbing factor is that previous investigation of airborne particulates and trace metal analysis leading to the evaluation of the human health risk for the nearby inhabitants in the area is scarce. This problem of scarcity of information applies to similar facilities in general in the Ghanaian industrial context. In response to these concerns, it was felt that data related to total suspended particulates (TSP) would be very useful and informative. The initial response was the instigation of air quality survey to determine the levels of TSP and trace metals contamination in the ambient air and furthermore establish the most polluted zones and the health risk on the affected population.

Health risks evaluation on human receptors due to heavy metal concentrations in dust have been performed in different parts of the world $[4,12,13]$. The objective of the present study was therefore to generate levels of environmental data regarding suspended dust and its trace metal (As, $\mathrm{Cr}, \mathrm{Ni}$ and $\mathrm{Zn}$ ) in the ambient air around DIACEM and to determine their risk on both adults and children population in the vicinity of the cement facility. The findings of the study would lead to recommendations on siting decisions of such industrial facilities.

\section{MATERIALS AND METHODS}

\subsection{Study area}

The study area is located at the South Eastern part of Ghana in the Volta region. The area is geographically enclosed between Latitudes $06.13400 \mathrm{~N}$ and $06.16650 \mathrm{~N}$ and Longitudes $01.16100 \mathrm{E}$ and $01.19911 \mathrm{E}$. The area is bounded on the: North by the eastern boarder of the Republic of Togo; East by the Aflao township; West by Akplorkploe; and South by a lagoon which floods a wide area. The DIACEM factory is located $3 \mathrm{~km}$ north of the Aflao Township (Fig. 1). It has two rainy seasons with the major rains in April to June, and the minor rains 
between September and November. Minimum temperatures in the investigated area are $13.5^{\circ} \mathrm{C}$ and occur between the months of August and September, and average maximum of $40^{\circ} \mathrm{C}$ is experienced between February and March.

The factory's surrounding area is essentially rural with minor agricultural activities. Settlements are scattered at one point and clustered at another at varying distances with the nearest settlement at about $300 \mathrm{~m}$ from the factory. The geological formations of the investigated area are rocks of the Dahomeyan series of the Precambrian age. These rocks consist of dense aggregate of essential stable minerals that are bounded and have medium to coarse-grained granite texture. The soil types are mainly lateritic sandy soils, tropical black clays, tropical gray earths, and sodium vleisols.

\subsection{Sampling and Analysis}

\subsubsection{Sample collection and preparation}

Air samples were collection around DIACEM for 16 different days in March 2013. The sampling sites were selected in such a manner to cover the entire geographical vicinity of the cement factory. To achieve this, concentric circles of radii $150 \mathrm{~m}, 300 \mathrm{~m}, 500 \mathrm{~m}$ and $700 \mathrm{~m}$ around the main stack of the cement facility were taken into consideration. On each circle eight sampling sites representing the north, north-east, east, south-east, south, south-west, west and north-west directions were created on a map (Fig. 1). On the field, these pre-determined points were located by means of a Geographical Positioning System (GPS). At least two sampling points representing each geographical axes of the factory were sampled, and the results computed into averages.

At the sampling points, air particulate matter (dust) was collected on a Hollingsworth and Vose Type HD-2064 $47 \mathrm{~mm}$ diameter fibre glass filter with the aid of SAIC Air Sampler

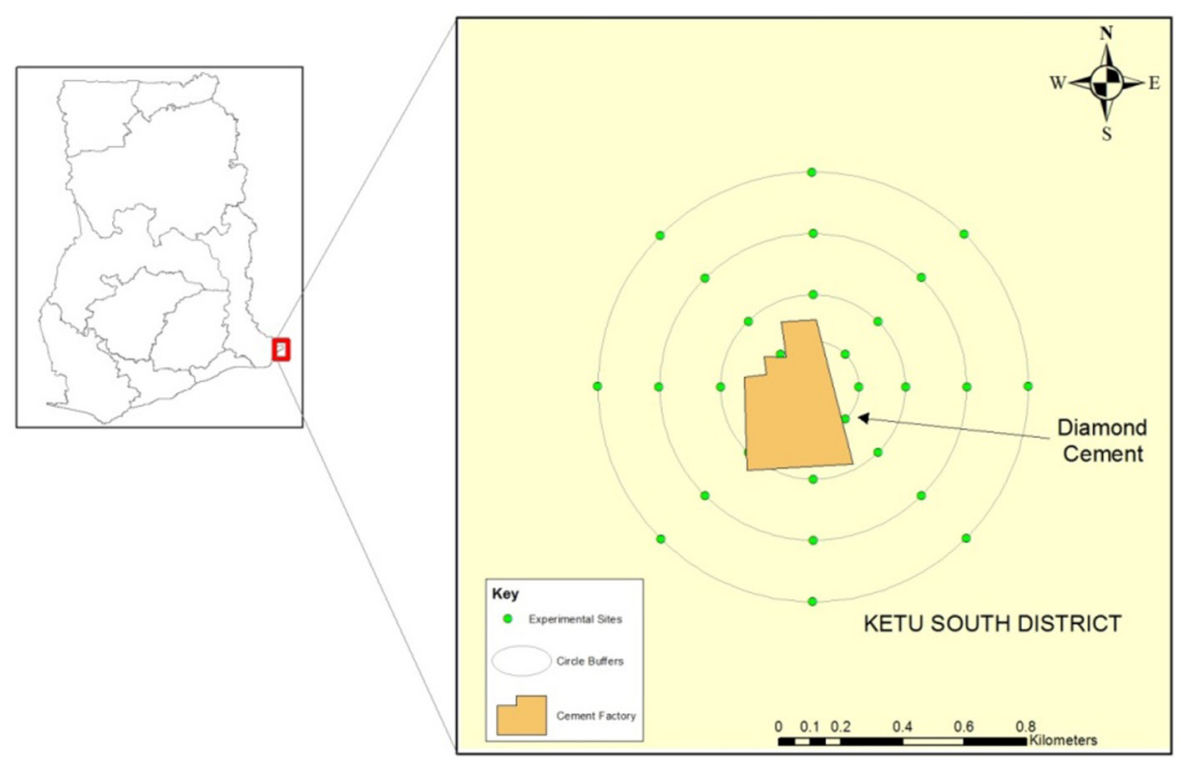

Figure 1: Location of the study area showing the sampling points around the DIACEM facility. 
12/24 VDC Model H-809C to determine TSP, the air sampler was equipped with flow-rate meter (Rotometer). The instrument with a flow rate of $350 \mathrm{~L} / \mathrm{min}$ has been calibrated by the manufacturer with SAIC-RADêCO CP-200 iodine cartridge and a $47 \mathrm{~mm} 0.3 \mu \mathrm{m}$ filter paper. The sampler was generally positioned at a height of $1.6 \mathrm{~m}$ from the ground on an adjustable tripod stand and generally isolated from buildings and obstacles that may hinder maximum dust from reaching the sampler. The sampling time was approximately 4 hours. Two different measurements were taken per each location, and the concentration results averaged out for the site. Before sampling, the filter was conditioned in a desiccator at 50\% relative humidity for 24 hours and weighed accurately on an analytical balance. The flow rate which was power supply dependent was observed throughout the sampling period. At the end of each sampling period, the filter paper was removed from the sampler and placed in a $20 \mathrm{~cm} \times 30 \mathrm{~cm}$ transparent polyethylene envelope. For easy identification, the sampling point codes were indicated on the envelopes.

The mass of particulate matter on the filters were weighed using a microbalance with an accuracy of $\pm 0.0001 \mathrm{~g}$. All samples were weighed three times in a row for repeatability, and the average was used as the pre- or post-sampling weight for gravimetric calculations. To prevent the filter paper from hand contamination, special pair of tongs was used for handling purposes. (1):

The average dust concentration for each filter paper was calculated using the following eqn

$$
\mathrm{C}=\frac{M_{\text {dust }}}{Q t}
$$
$\mathrm{m}^{3}$;

Where $\mathrm{M}_{\text {dust }}=$ mass of dust collected on each filter, $\mathrm{g} ; \mathrm{C}=$ average dust concentration, $\mu \mathrm{g} /$

$\mathrm{Q}=$ average sampler pump flow rate during sample period, $\mathrm{L} / \mathrm{min} ; \mathrm{t}=$ length of the sampling period in minutes.

\subsubsection{Instrumental Neutron-Activation Analysis (INAA) of filters}

The elemental analysis of the filter papers was carried out Figusing instrumental neutronactivation analysis (INAA). INAA has previously been shown to be feasible for multi-elemental determination in geological samples [14]. Each filter paper was folded into eight equal sectors, and the whole piece pushed into a rabbit capsule and sealed thermally before irradiation. Each sample was coded accordingly to the sampling location.

To validate the accuracy of the instrumentation, a series of geological standard reference materials (SRM) were prepared, irradiated and analyzed in the same manner as the analytical samples. The geological standards used were: Rock Reference Materials GBW07106 and GBW07107, all purchased from the Institute of Marine Geology in China; and IAEA CRM SL-1 Lake Sediment. In the preparation of the standards, a blank filter paper was treated by spreading the standard material of approximately $0.010 \mathrm{~g}$ on it and encapsulated as was done to the analytical samples. The standards were used to validate the accuracy of the instrumentation employed for this work.

\subsection{Irradiation and counting}

Both the analytical samples and the SRMs were irradiated at Ghana Research Reactor-1 (GHARR-1) Centre, Ghana Atomic Energy Commission. The neutron flux used for the 
irradiation was approximately $5.0 \times 10^{11} \mathrm{n} / \mathrm{cm}^{2} \mathrm{~s}$. The samples were sent into the miniature neutron source reactor by means of a pneumatic transfer system operating at a pressure of 25 atmospheres. The scheme of the irradiation was chosen so as to take into account the half $\bullet$ lives of the radionuclides of interest. In that regard, the following irradiation times were selected: $10 \mathrm{~s}$ for the medium-lived radionuclide $\left({ }^{76} \mathrm{As}\right)$; and $54,000 \mathrm{~s}$ for the long-lived radionuclide $\left({ }^{51} \mathrm{Cr},{ }^{58} \mathrm{Ni}\right.$ and $\left.{ }^{65} \mathrm{Zn}\right)$.

After $24 \mathrm{hr}$ decay period, the activity of the gamma ray emitting radionuclides with medium half $\bullet$ lives was measured. Similarly, the gamma spectral intensities for the long half $\bullet$ life radionuclides were also measured between 2 and 4 weeks decay period.

The measurements of the gamma ray spectral intensities were made using a spectroscopy system of the high-purity germanium (HPGe) N•type coaxial detector model GR2581; high-voltage power supply model 3105; and a spectroscopy amplifier model 2020 (all manufactured by Canberra Industries, Inc.,). The detector system at fixed geometry was coupled with an $8 \mathrm{k}$ Ortec multiøchannel analyzer (MCA) emulation card and a 486 microcomputer. The resolution of the detector system which operates at a bias voltage of $-3000 \mathrm{~V}$ full width at half maximum was $1.8 \mathrm{keV}$ for ${ }^{60} \mathrm{Co} 1332 \mathrm{keV}$ gamma ray with $25 \%$ relative efficiency.

The output spectral intensities of both the analytical samples and standards were processed and stored in the microcomputer software by means of the MCA card. Qualitative analysis of the radioisotopes was achieved by means of identifying their spectral intensities. The evaluation of the areas through integration under the photopeaks of the identified elements was converted into their concentrations using the comparator method [15] which is given by the comparator Eqn (2) below:

$$
\frac{C_{s a m}}{C_{s t d}}=\frac{A_{s a m}}{A_{s t d}}
$$

Where $\mathrm{C}_{\text {std }}=$ Known standard concentration in $\mathrm{mg} / \mathrm{kg}, \mathrm{C}_{\text {sam }}=$ Known analyte concentration in $\mathrm{mg} / \mathrm{kg}$,

$\mathrm{A}_{\text {std }}=$ Specific net area of standard element, $\mathrm{A}_{\text {sam }}=$ Specific net area of analyte element.

In deriving Eqn (2), it is assumed that the neutron flux $\left(\mathrm{ncm}^{-2} \mathrm{~s}^{-1}\right)$, cross sections, irradiation times (s) and all other variable parameters associated with counting are constant for both the standard and sample.

\subsection{Zonation of study area}

The study area was partitioned into four zones. The zones are quadrants or quarter area of a circle with the cement factory in the centre. The location and characteristics of the zones is presented in Table 1. It is important to note that the direction of the prevailing wind in the area was from Zone 3 to Zone 1.

\subsection{Risk assessment model}

The population in the vicinity of DIACEM exposure to the trace elements in the airborne particulates was assessed via the usual three pathways: direct ingestion $\left(\mathrm{ADD}_{\text {ing }}\right)$; inhalation $\left(\mathrm{ADD}_{\mathrm{inh}}\right)$; and dermal absorption $\left(\mathrm{ADD}_{\text {derm }}\right)$. The dose received by the human body due to the above pathways was considered as daily doses. Exposure levels was separately calculated for each element and for each exposure pathways using the following eqns (3)-(5) which 
Table 1: Location and characteristics of zones for the study area.

\begin{tabular}{|c|c|c|c|}
\hline Zone no. & Location & Geographical axes & Characteristics \\
\hline 1. & Upper duta & $\begin{array}{l}\text { Between north and } \\
\text { north-east }\end{array}$ & $\begin{array}{l}\text { Residential area; untarred routs; } \\
\text { school; pockets of farmlands; } \\
\text { open wells and boreholes }\end{array}$ \\
\hline 2. & Lower duta & south and south-east & $\begin{array}{l}\text { Large stretch of farmlands; minor } \\
\text { settlements close to factory; water } \\
\text { body }\end{array}$ \\
\hline 3. & $\begin{array}{l}\text { Lower akplork- } \\
\text { ploe }\end{array}$ & west and south-west & $\begin{array}{l}\text { Lower Diacem-Aflao road; resi- } \\
\text { dential; farmlands; church build- } \\
\text { ing; school ect. }\end{array}$ \\
\hline 4. & $\begin{array}{l}\text { Upper } \\
\text { akplorkploe }\end{array}$ & west and north-west & $\begin{array}{l}\text { Upper Diacem-Aflao road; health } \\
\text { facility; Residential area; untarred } \\
\text { routs; sch.; pockets of farmlands; } \\
\text { numerous open well; large coconut } \\
\text { plantations etc. }\end{array}$ \\
\hline
\end{tabular}

were based on those developed by the US Environmental Protection Agency [16] and have been widely applied in human-risk assessment investigations $[10,17,18]$.

$$
\begin{gathered}
\mathrm{ADD}_{\text {ing }}=C x \frac{\operatorname{IngRxEFxED}}{B W x A T} \times 10^{-6} \\
\mathrm{ADD}_{\text {ing }}=C x \frac{\operatorname{IngRxEFxED}}{P E F x B W x A T} \\
\mathrm{ADD}_{\text {derm }}=C x \frac{S L x S A x A B S x E F X E D}{B W x A T} \times 10^{-6}
\end{gathered}
$$

The symbols and parameters used indicated in the health risk assessment models are indicated in Table 2 below.

From the pathways exposure results, a Hazard Quotient (HQ) based on non-cancer toxic risk was then calculated by dividing the average daily value by a specific reference dose (RfD) [18].

- The ABS for only arsenic is 0.03

$$
\mathrm{HQ}=\mathrm{ADD} / \mathrm{RfD}
$$

The reference dose $(\mathrm{mg} / \mathrm{kg} /$ day $)$ is an estimation of the maximum permissible risk on human population through daily exposure, taking into consideration a sensitive group during a lifetime [21]. The threshold value of RfD can be used to indicate whether there was an adverse health effect during a life time. For the non-cancer health risk, the HQs of each dose were added to generate a Hazard Index (HI) used to estimate the risk of mixed contaminates:

$$
\mathrm{HI}=\sum \mathrm{HQ} i
$$


Where $i$ correspond to different contaminants under consideration. $\mathrm{HI} \leq 1$ indicated no adverse health effects and $\mathrm{HI}>1$ indicated likely adverse health effects [19].

The assessment of cancer risk was made by calculating the lifetime average daily dose (LADD) as a weighted average for each exposure pathway and is given in the following eqn [20]:

$$
L A D D\left(m g K^{-1} \text { day }^{-1}\right)=\frac{C \times E F}{A T} \times\left(\frac{C R_{\text {child }} \times E D_{\text {child }}}{B W_{\text {child }}}+\frac{C R_{\text {adult }} \times E D_{\text {adult }}}{B W_{\text {adult }}}\right) \times 10^{-6}
$$

Where all the symbols denote the same variables as Table 2, however, CR denotes the contact rate that is for ingestion $(\mathrm{CR}=\mathrm{IngR})$, for inhalation $(\mathrm{CR}=\mathrm{InhR})$ and for dermal absorption $(\mathrm{CR}=\mathrm{SA} \times \mathrm{SL} \times \mathrm{ABS})$.

\section{RESULTS AND DISCUSSIONS}

\subsection{Analytical method validation}

The instrumentation used in the trace metal analysis was validated by the determination of As, Cr, Ni and Zn in the Standard reference Materials (SRMs), GBW07106 and GBW7107. The results of the validation studies are presented in Table 3. In Table 3, the trace metal certification as verified by the Institute of Marine Geology, China, using INAA technique is shown. These results show that our analytical procedures provided data within the acceptable range of the certified values.

Table 2: Parameters used for human exposure and human-risk assessment.

\begin{tabular}{|c|c|c|c|c|c|}
\hline \multirow[b]{2}{*}{ Parameter } & \multirow[b]{2}{*}{ Description } & \multicolumn{2}{|c|}{ Value } & \multirow[b]{2}{*}{ Unit } & \multirow[b]{2}{*}{ References } \\
\hline & & Adults & Children & & \\
\hline IngR & Ingestion rate & 100 & 200 & mg day ${ }^{-1}$ & {$[19]$} \\
\hline $\operatorname{InhR}$ & Inhalation rate & 20 & 7.6 & $\mathrm{~m}^{3}$ day $^{-1}$ & {$[12]$} \\
\hline $\mathrm{EF}$ & Exposure frequency & 350 & 350 & day year-1 & [17] \\
\hline ED & Exposure duration & 24 & 6 & year & $\begin{array}{l}\text { This work, } \\
2012\end{array}$ \\
\hline SA & Exposed skin area & 5700 & 2800 & $\mathrm{~cm}^{2}$ & [19] \\
\hline SL & Skin adherence factor & 0.7 & 0.2 & $\mathrm{mg} \mathrm{cm}^{-2} \mathrm{~h}^{-1}$ & {$[19]$} \\
\hline PEF & Particle emission factor & $1.36 \times 10^{9}$ & $1.36 \times 10^{9}$ & $\mathrm{~m}^{3} \mathrm{~kg}$ & {$[19]$} \\
\hline BW & Average body weight & 70 & 15 & $\mathrm{~kg}$ & {$[19]$} \\
\hline AT & Averaging time & $\begin{array}{l}\mathrm{ED} \times 365 \\
70 \times 365\end{array}$ & $\begin{array}{l}\text { For non-car } \\
\text { For carcino }\end{array}$ & $\begin{array}{l}\text { rcinogens } \\
\text { gens }\end{array}$ & {$[17]$} \\
\hline ET & Exposure time & 24 & 24 & hour day ${ }^{-1}$ & {$[12]$} \\
\hline $\mathrm{RfC}$ & Reference conc. & \multicolumn{2}{|c|}{ Chemical specific } & $\mathrm{mg} \mathrm{m}^{-3}$ & {$[14]$} \\
\hline$R f D_{0}$ & Reference dose & \multicolumn{2}{|c|}{ Chemical specific } & $\mathrm{mg} \mathrm{kg}^{-1}$ day $^{-1}$ & {$[14]$} \\
\hline $\mathrm{ABS}$ & Dermal absorb factor & \multicolumn{2}{|c|}{0.001 for all elements } & unitless & {$[19]$} \\
\hline $\mathrm{C}$ & Exposure-point conc. & \multicolumn{2}{|l|}{ Site specific } & $\mathrm{mg} \mathrm{kg}^{-1}$ & [19] \\
\hline
\end{tabular}




\subsection{Ambient dust concentration}

Table 4 summarizes the statistical parameters pertaining to the concentration and distribution levels of TSP in the vicinity of DIACEM factory. The data set were distributed among four zones created around the facility. The mean values of the TSP at the various locations were $932.88,363.48,340.14$ and $390.53 \mu \mathrm{g} / \mathrm{m}^{3}$ for zones $1,2,3$ and 4 , respectively, giving an overall mean of $538.92 \mu \mathrm{g} / \mathrm{m}^{3}$ for the communities surrounding the DIACEM facility. This value is over three times higher than the permissible limit of $150.0 \mu \mathrm{g} / \mathrm{m}^{3}$ specified by the Ghana Environment Protection Agency (EPA) for a rural setting.

The inter-zonal variations were significant $\left(\mathrm{F}_{(3,16)}=4.73 ; \mathrm{p}<0.05\right)$ between zone 1 , and the other zones which did not show any significant differences among themselves. The highest concentration of TSP was in Zone 1 where the prevailing wind across DIACEM is designated. At period of sampling the dry whether condition let loose the dust particles at the sampling points. Hence, all loose dusts from various activities in the factory are directed towards that direction. The spatial variations of TSP, which were not significant among the other zones

Table 3: Comparison of elemental concentration in various standard reference materials with measured laboratory values.

\begin{tabular}{|c|c|c|c|c|c|}
\hline Elements & Referencematerials & $\begin{array}{l}\text { No. of } \\
\text { measure- } \\
\text { ments }\end{array}$ & $\begin{array}{l}\text { Results from } \\
\text { this study }\end{array}$ & Reported values & Units \\
\hline As & GBW7106 & 3 & $8.68 \pm 0.76$ & $9.10 \pm 1.80$ & $\mu \mathrm{g} / \mathrm{g}$ \\
\hline $\mathrm{Cr}$ & GBW7107 & 3 & $102.33 \pm 5.79$ & $99.0 \pm 8.00$ & $\mu \mathrm{g} / \mathrm{g}$ \\
\hline $\mathrm{Ni}$ & GBW7107 & 3 & $35.53 \pm 2.96$ & $37.0 \pm 4.00$ & $\mu \mathrm{g} / \mathrm{g}$ \\
\hline $\mathrm{Zn}$ & GBW7107 & 3 & $56.87 \pm 6.88$ & $55.0 \pm 6.00$ & $\mu \mathrm{g} / \mathrm{g}$ \\
\hline
\end{tabular}

Table4: Statistical summary of airborne dust $\left(\mu \mathrm{g} / \mathrm{m}^{3}\right)$ and trace metal concentration $(\mathrm{mg} / \mathrm{kg})$ among the zones of the study area.

\begin{tabular}{|c|c|c|c|c|c|c|}
\hline $\begin{array}{l}\text { Dust/ } \\
\text { Metal }\end{array}$ & $\begin{array}{l}\text { Statist. } \\
\text { factors }\end{array}$ & Zone 1 & Zone 2 & Zone 3 & Zone 4 & $\begin{array}{l}\text { Whole Area } \\
\text { Values }\end{array}$ \\
\hline \multirow[t]{2}{*}{ Dust } & Range & $\begin{array}{l}293.33- \\
1771.13\end{array}$ & $222.92-543.01$ & $217.86-474.76$ & $\begin{array}{l}304.12- \\
596.08\end{array}$ & $\begin{array}{l}217.86- \\
1771.13\end{array}$ \\
\hline & Mean & 932.88 & 363.48 & 340.14 & 390.56 & 506.77 \\
\hline \multirow[t]{2}{*}{ As } & Range & $0.78-3.50$ & $2.35-8.12$ & $2.13-8.22$ & $0.35-6.38$ & $0.35-8.12$ \\
\hline & Mean & 1.91 & 4.31 & 4.54 & 1.96 & 2.87 \\
\hline \multirow[t]{2}{*}{$\mathrm{Cr}$} & Range & $9.75-14.57$ & $6.46-19.35$ & $6.04-22.91$ & $2.69-39.96$ & $2.69-39.96$ \\
\hline & Mean & 12.10 & 13.87 & 16.40 & 19.03 & 15.26 \\
\hline \multirow[t]{2}{*}{$\mathrm{Ni}$} & Range & $12.53-35.28$ & $34.68-99.28$ & $33.20-56.02$ & 13.96-86.24 & $12.53-99.28$ \\
\hline & Mean & 25.88 & 63.22 & 43.81 & 47.46 & 44.38 \\
\hline \multirow[t]{2}{*}{ Zn } & Range & $5.95-33.07$ & $17.43-58.49$ & $21.45-27.90$ & $20.57-36.93$ & $5.95-58.49$ \\
\hline & Mean & 17.48 & 34.04 & 23.73 & 27.77 & 25.65 \\
\hline
\end{tabular}


could probably suggest that those areas were impacted upon from similar sources. However, judging from Table 4, it can be inferred that the lowest dust levels was in Zone 3 (source of the prevailing wind). This suggests that the local meteorology in terms of wind speed and direction also influences cement dust distribution at each sampling location in the area.

Meanwhile, DIACEM could be partly held responsible for major dust levels and distribution in the area, as there is no other industrial facility within a radius of $30 \mathrm{~km}$ from it. A number of health-related problems may be associated with the elevation of TSP levels in the atmosphere. In that regard, the current TSP levels can be said to be very disturbing, during the sampling period. Under long-term exposure, there is a correlation between particle concentration and mortality from lung diseases [22]. Health effects of suspended particulate matter (SPM) in humans depend on particle size, concentration and exposure time [23]. Exposure of $200 \mu \mathrm{g} / \mathrm{m}^{3}$ of particulate matter for a long time can cause upper respiratory disease and between 294 and $470 \mu \mathrm{g} / \mathrm{m}^{3}$ depress immune function in children [22].

It is worth comparing the finding of the total dust levels of the current study with those of others around other cement facilities. For instance, the average mean concentration in this study was higher than those conducted by Ali-Khodja et al., [24] in Algeria, Oguntoke et al., [25] in south-west Nigeria, and Khamparia et al., [26] in India. Similarly, the total dust level by this study was found less than those performed by Tiwari et al., [27] in Iran and Zeleke et al., [28] in Ethiopia. The difference in levels of total dust may probably due to newer technology and effective control measures adopted by individual countries and more importantly the environmental conditions.

\subsection{Elemental concentrations in TSP}

The mean concentration for different trace metals at the different zones are shown in Table 4. The overall highest mean concentration was found for $\mathrm{Ni}$ at $44.38 \mu \mathrm{g} / \mathrm{m}^{3}$, followed by $\mathrm{Zn}$ $(25.65 \mathrm{mg} / \mathrm{kg}), \mathrm{Cr}(15.65 \mathrm{mg} / \mathrm{kg})$ and As $(2.87 \mathrm{mg} / \mathrm{kg})$. The same elemental concentration trend pattern was observed among the various zones in the study area. The zonal trend exposure could be attributed to a fact that the zones derived the airborne metal concentration from a common source. This further confirmed the cement factory's operations as having a huge influence to these metal generation and distribution in the study area.

The level of metal distribution among the zones for $\mathrm{Ni}$ and $\mathrm{Zn}$ is similar. They exhibited a mean decreasing concentration trend as follows: Zone $2>$ Zone $4>$ Zone $3>$ Zone 1 . The results of Table 4 further revealed that zone 1 which recorded the highest concentration of TSP is rather least concentrated in all aspects of the trace metals under the current study. This further supports the fact that the airborne elements apart from the cement facility contribution might be derived from other sources. For instance, the Aflao-DIACEM roadway, which is operated upon by heavy vehicular traffic is located in Zones 3 and 4. Traffic of vehicles, especially trucks, operating at the proximity of the cement plant may cause metal distribution into the roadsoil through the deposition of cement dust and exhaust fumes, which may re-suspend into the atmosphere. Roadside soils are noted to contain huge influx of heavy metals $[29,30]$.

\subsection{Human health risk assessment}

Data on exposure for trace metals for children and adults population living within the zones around the cement plant is shown in Table 5. The main direct exposure corresponds to 
Table 5: Dose ( $\mathrm{mg} / \mathrm{kg} / \mathrm{day})$ range due to non-cancerous elements in suspended dust various zones of DIACEM.

\begin{tabular}{|c|c|c|c|c|c|c|c|c|c|}
\hline \multirow[b]{2}{*}{ Metal } & \multirow[b]{2}{*}{ Pathway } & \multicolumn{2}{|c|}{ Zone 1} & \multicolumn{2}{|c|}{ Zone 2} & \multicolumn{2}{|c|}{ Zone 3} & \multicolumn{2}{|c|}{ Zone 4} \\
\hline & & $\begin{array}{c}\text { Adult } \\
\text { (A) }\end{array}$ & $\begin{array}{l}\text { Child } \\
\text { (C) }\end{array}$ & A & C & $\mathbf{A}$ & C & A & $\mathbf{C}$ \\
\hline \multirow[t]{3}{*}{$\overline{\mathrm{As}}$} & Inh. $\times 10^{-10}$ & 3.85 & 1.71 & 8.86 & 3.85 & 9.15 & 4.05 & 3.95 & 1.75 \\
\hline & Ing. $\times 10^{-6}$ & 2.62 & 6.11 & 5.9 & 13.8 & 6.22 & 14.5 & 2.69 & 6.27 \\
\hline & Der. $\times 10^{-8}$ & 5.13 & 3.48 & 11.6 & 7.85 & 12.2 & 8.27 & 5.26 & 3.57 \\
\hline \multirow[t]{3}{*}{$\mathrm{Cr}$} & Inh. $\times 10^{-9}$ & 2.44 & 1.08 & 2.97 & 1.24 & 3.30 & 1.46 & 3.21 & 1.42 \\
\hline & Ing. $\times 10^{-5}$ & 1.66 & 3.87 & 1.9 & 4.43 & 2.25 & 5.24 & 2.19 & 5.10 \\
\hline & Der. $\times 10^{-7}$ & 3.25 & 2.21 & 3.72 & 2.53 & 4.40 & 2.99 & 4.30 & 2.29 \\
\hline \multirow[t]{3}{*}{$\mathrm{Ni}$} & Inh. $\times 10^{-9}$ & 5.21 & 2.31 & 12.7 & 5.65 & 8.83 & 3.91 & 10.2 & 4.54 \\
\hline & Ing. $\times 10^{-5}$ & 3.55 & 8.27 & 8.66 & 20.2 & 6.00 & 14.0 & 6.96 & 16.2 \\
\hline & Der. $\times 10^{-7}$ & 6.95 & 4.72 & 17.0 & 11.5 & 11.7 & 7.98 & 13.5 & 9.26 \\
\hline \multirow[t]{3}{*}{$\mathrm{Zn}$} & Inh. $\times 10^{-9}$ & 3.52 & 1.56 & 6.87 & 3.05 & 4.78 & 2.12 & 5.74 & 2.54 \\
\hline & Ing. $\times 10^{-5}$ & 2.40 & 5.59 & 4.66 & 10.9 & 3.25 & 7.59 & 3.90 & 9.11 \\
\hline & Der. $\times 10^{-7}$ & 4.70 & 3.19 & 9.12 & 6.21 & 6.37 & 4.32 & 7.65 & 5.19 \\
\hline
\end{tabular}

Table 6: Relative toxicity values used in this study.

\begin{tabular}{|c|c|c|c|}
\hline & Inhalation & Ingestion & Dermal \\
\hline Elements & \multicolumn{3}{|c|}{ Non-Carcinogenic } \\
\hline As & - & $3.00 \mathrm{E}-04$ & $1.23 \mathrm{E}-04$ \\
\hline $\mathrm{Cr}$ & $2.86 \mathrm{E}-05$ & $3.00 \mathrm{E}-03$ & $6.00 \mathrm{E}-05$ \\
\hline $\mathrm{Ni}$ & $2.00 \mathrm{E}-03$ & $2.00 \mathrm{E}-02$ & $5.4 \mathrm{E}-03$ \\
\hline $\mathrm{Zn}$ & \multicolumn{2}{|c|}{ Carcinogenic } & $6.00 \mathrm{E}-02$ \\
\hline As & 1.50 & $1.51 \mathrm{E} 01$ & 3.66 \\
\hline $\mathrm{Cr}$ & $4.20 \mathrm{E}-01$ & - & - \\
\hline $\mathrm{Ni}$ & 8.40E-01 & - & - \\
\hline
\end{tabular}

ingestion pathway for all the metals within the various zones for both adults and children. Nickel is the most ingested element in the ambient dust surrounding the cement facility with As the least. Zone 2 experiences the most $\mathrm{Ni}$ exposure in terms of ingestion. In general, the minor exposure pathway of trace metals in the area corresponds to inhalation exposure. In respect of inhalation and dermal contact exposure pathways, adults are more liable than children, whilst ingestion pathway is more likely in children than in adults.

In this study, quantified risk for both carcinogenic and non-carcinogenic effects was applied to each exposure pathway in the analysis. The relative toxicity values used in the analysis were summarized from literature as shown in Table 6 [10,18,21]. 
Arsenic and $\mathrm{Zn}$ toxicity values considered for inhalation route were substituted by the corresponding oral doses and slope factors with the assumption that, after inhalation, the absorption of the particle-bound toxicant will result in similar health effects [21]. With respect to the non-carcinogenic risks, the values of the hazard quotients (HQ) as well as their corresponding Hazard Indices (HIs) of each metal in all the zonal areas were lower than unity, which is defined as the safety value. The non-cancer HQ and HI estimate based on concentration of individual metals is presented in Table 7.

According to the study statistics, the HQ for non-cancerous effects in Table 7 are higher for the ingestion route for each exposure route for each metal followed by dermal absorption exposure pathway with inhalation expose route being the lowest. The contribution of HQs ingestion to the HIs is the highest and not less than $70 \%$ for each metal. The trend of the different pathway exposures is the same among all the different zones surrounding the cement facility. It can be realized that ingestion is far higher for children than for adults making the overall exposure routes higher for children than adults. This result emphasizes earlier findings $[18,21]$ in the study of airborne metals around some industrial facilities, where risk estimates are always higher for children than adults. Zone 3 which is the most highly populated, recorded the highest $\mathrm{HI}$ for both adults and children with the potential health risk hinging more on the children population. On the whole, HI values for the metals decrease in the order $\mathrm{As}>\mathrm{Cr}>\mathrm{Ni}>\mathrm{Zn}$ around the cement facility.

Table 7: Hazard quotient and Hazard Index of non-cancerous elements for each exposure pathway within the zones rounding DIACEM.

\begin{tabular}{|c|c|c|c|c|c|c|c|c|c|}
\hline \multirow[b]{3}{*}{ Metal } & \multirow[b]{3}{*}{ Pathway } & \multicolumn{8}{|c|}{ Hazard Quotient (HQ) } \\
\hline & & \multicolumn{2}{|c|}{ Zone 1} & \multicolumn{2}{|c|}{ Zone 2} & \multicolumn{2}{|c|}{ Zone 3} & \multicolumn{2}{|c|}{ Zone 4} \\
\hline & & A & $\mathrm{C}$ & $\mathrm{A}$ & $\mathrm{C}$ & A & $\mathrm{C}$ & A & $\mathrm{C}$ \\
\hline \multirow[t]{3}{*}{$\overline{\text { As }}$} & Inh. $\times 10^{-9}$ & 1.28 & 0.57 & 2.95 & 1.28 & 3.05 & 1.35 & 1.32 & 0.58 \\
\hline & Ing. $\times 10^{-6}$ & 8.73 & 20.4 & 19.7 & 46.0 & 20.7 & 48.3 & 9.00 & 20.9 \\
\hline & Der. $\times 10^{-7}$ & 4.17 & 2.83 & 9.43 & 6.38 & 9.92 & 6.72 & 4.28 & 2.90 \\
\hline$\Sigma \mathrm{HQ}_{\mathrm{As}}$ & HI $\left(\times 10^{-5}\right)$ & 0.92 & 2.07 & 2.06 & 4.66 & 2.17 & 4.90 & 0.94 & 2.12 \\
\hline \multirow[t]{3}{*}{$\mathrm{Cr}$} & Inh. $\times 10^{-8}$ & 8.53 & 3.78 & 10.4 & 4.34 & 11.5 & 5.11 & 11.2 & 4.97 \\
\hline & Ing. $\times 10^{-6}$ & 5.53 & 12.9 & 6.33 & 14.8 & 7.50 & 17.5 & 7.30 & 17.0 \\
\hline & Der. $\times 10^{-6}$ & 5.42 & 3.68 & 6.20 & 4.22 & 7.33 & 4.98 & 7.17 & 3.82 \\
\hline$\Sigma \mathrm{HQ}_{\mathrm{Cr}}$ & HI $\left(\times 10^{-5}\right)$ & 1.10 & 1.66 & 1.26 & 1.91 & 1.49 & 2.25 & 1.46 & 2.09 \\
\hline \multirow[t]{3}{*}{$\mathrm{Ni}$} & Inh. $\times 10^{-9}$ & 2.61 & 1.16 & 6.35 & 2.83 & 4.42 & 1.96 & 5.10 & 2.27 \\
\hline & Ing. $\times 10^{-6}$ & 17.8 & 4.14 & 4.33 & 10.1 & 3.00 & 7.00 & 3.48 & 8.10 \\
\hline & Der. $\times 10^{-7}$ & 1.29 & 0.87 & 3.15 & 2.13 & 2.17 & 1.48 & 2.50 & 1.72 \\
\hline$\Sigma \mathrm{HQ}_{\mathrm{Ni}}$ & HI $\left(\times 10^{-6}\right)$ & 19.1 & 4.23 & 4.65 & 10.3 & 3.22 & 7.15 & 3.74 & 1.72 \\
\hline \multirow[t]{3}{*}{$\mathrm{Zn}$} & Inh. $\times 10^{-11}$ & 1.17 & 0.52 & 2.29 & 1.02 & 1.59 & 0.71 & 1.91 & 0.85 \\
\hline & Ing. $\times 10^{-7}$ & 0.80 & 1.86 & 1.55 & 3.63 & 1.08 & 2.53 & 1.30 & 3.04 \\
\hline & Der. $\times 10^{-8}$ & 0.78 & 0.53 & 1.52 & 1.04 & 1.06 & 0.72 & 1.28 & 0.87 \\
\hline$\Sigma \mathrm{HQ}_{\mathrm{Zn}}$ & HI $\left(\times 10^{-7}\right)$ & 0.88 & 1.91 & 1.70 & 3.73 & 1.19 & 2.60 & 1.43 & 3.13 \\
\hline
\end{tabular}


Table 8: Lifetime average daily dose LADD ( $\mathrm{mg} / \mathrm{Kg} /$ day) values of cancerous elements.

\begin{tabular}{|c|c|c|c|c|c|c|}
\hline \multirow[b]{2}{*}{ Metal } & \multirow[b]{2}{*}{ Pathway } & \multicolumn{4}{|c|}{ Locations } & \multirow{2}{*}{$\begin{array}{c}\text { Average } \\
\text { values }\end{array}$} \\
\hline & & Zone 1 & Zone 2 & Zone 3 & Zone 4 & \\
\hline \multirow[t]{3}{*}{$\overline{\mathrm{As}}$} & Inhalation & 3.89E-07 & $8.76 \mathrm{E}-07$ & $9.24 \mathrm{E}-07$ & 3.99E-07 & $6.47 \mathrm{E}-07$ \\
\hline & Ingestion & $4.51 \mathrm{E}-05$ & $1.02 \mathrm{E}-04$ & $1.07 \mathrm{E}-04$ & 4.64E-05 & $7.51 \mathrm{E}-05$ \\
\hline & Dermal & $1.53 \mathrm{E}-07$ & $3.44 \mathrm{E}-07$ & $3.62 \mathrm{E}-07$ & $1.56 \mathrm{E}-07$ & $2.54 \mathrm{E}-07$ \\
\hline \multirow[t]{2}{*}{$\mathrm{Cr}$} & Inhalation & $6.89 \mathrm{E}-07$ & $7.90 \mathrm{E}-07$ & 9.32E-07 & $9.07 \mathrm{E}-07$ & $8.30 \mathrm{E}-07$ \\
\hline & Ingestion & 7.94E-06 & $9.11 \mathrm{E}-06$ & $1.08 \mathrm{E}-05$ & $1.05 \mathrm{E}-05$ & $9.59 \mathrm{E}-06$ \\
\hline \multirow[t]{2}{*}{$\mathbf{N i}$} & Inhalation & $2.95 \mathrm{E}-06$ & $7.20 \mathrm{E}-06$ & 4.99E-06 & $5.79 \mathrm{E}-06$ & $5.23 \mathrm{E}-06$ \\
\hline & Ingestion & $3.40 \mathrm{E}-05$ & $8.32 \mathrm{E}-05$ & $5.76 \mathrm{E}-05$ & $6.69 \mathrm{E}-05$ & $6.04 \mathrm{E}-05$ \\
\hline
\end{tabular}

For carcinogenic risk, calculated LADD combines both adults and children using eqn (8). Data for the estimated cancer risk for the metals were carried out by multiplying the cancer slope factor with the LADD. Carcinogenic risks were only estimated for those metals whose slope factor has been already established. This refers to the cases of ingestion, dermal absorption and inhalation of $\mathrm{As}$, as well as $\mathrm{Cr}$ and $\mathrm{Ni}$ inhalation. Cancer-risk estimates calculated based on measured airborne metal concentration around the various zones of the cement facility are presented in Table 8.

The acceptable excess of cancer risk for a lifetime exposure for an individual is set at 1.0 $\times 10^{-5}[13]$. The estimation shows that the average inhalation pathways for all the carcinogenic metals were $<10^{-5}$ as well as dermal absorption on the part of As. The inhalation carcinogenic risk due to the metals ranged between a mean value of $6.47 \times 10^{-7}$ and $5.23 \times$ $10^{-6}\left(9.2 \times 10^{-7}\right.$ and $7.2 \times 10^{-6}$, respectively, for maximum values). Meanwhile, with the exception of $\mathrm{Cr}, \mathrm{Ni}$ and As values were found higher than the safe limit for ingestion route suggesting potential health risk for the human receptors in the vicinity of the cement facility. The overall ranged of values were from $9.59 \times 10^{-6}$ for $\mathrm{Cr}$ and $7.51 \times 10^{-5}$ for As. The carcinogenic risk statistics indicated that Zone 3 would experience the most ingestion cancer risk from As and $\mathrm{Cr}$ having recorded $1.07 \times 10^{-4}$ and $1.08 \times 10^{-5}$ respectively, with Zone 2 suffering the same fate from $\mathrm{Ni}\left(8.32 \times 10^{-5}\right)$. Ni inhalation for the people in Zone 2 could also impact a potential carcinogenic health risk as $7.2 \times 10^{-6}$ is so closer for safety concerns.

\section{CONCLUSION}

The study has indicated that there was massive air pollution around the DIACEM facility. It can be deduced from the dust measurement results that non-carcinogenic health issues related to the population surrounding the DIACEM facility was insignificant as all the HI values were less than unity. However, cancer risk in the area could be potentially possible, the exposure pathway which results in the highest level of risk for children and adults exposed to airborne dust is ingestion, and $\mathrm{As}$ and $\mathrm{Ni}$ are regarded as the most probable culprits to the health risk. It must be noted that health risk assessment is subjected to a great variability, hence the current results cannot be used to prompt a conclusion that the situation represent similar scenario around other cement facilities in Ghana because methods of operation, air pollution cleaning strategies, different metrological conditions and anthropogenic activities within the environs of such facilities may differ significantly. The problem is that reports and 
investigations on the toxicity values and exposure parameters in the cement industry in Ghana are scanty. Therefore, the present study must be seen only as a wake-up call to the environmental research community in Ghana to do more on data generation. By doing so, the siting of future cement plants in Ghana will be based on well-informed scientific decisions.

The study was conducted for within a period of $1 \mathrm{month}$; therefore the data were limited in terms of temporal seasonal variability. It is important that long-term exposure to elevated levels of trace metals present in the ambient air should have been considered. Therefore, further studies are necessary to collect adequate information to develop trends in risk assessment investigations.

\section{ACKNOWLEDGEMENT}

The authors through the University of Ghana are very grateful to Carnegie Next Generation for Academic in Africa (CNGAA) for providing funds which supported most part of the work.

\section{REFERENCES}

[1] Abdulkkareem A.S., Urban Air pollution by Computer Simulation: A Case Study of PetroleumRefining Company, Chemical Engineering Department, Federal University of Technology: Minna Niger State, Nigeria, 2008.

[2] Tajudeen, Y., Okpuzor, J. \& Fausat, A.T., Investigation of general effects of cement dust to clear the controversy surrounding its toxicity. Asian Journal of Scientific Research, 4(4), pp. 315-325, 2011.

http://dx.doi.org/10.3923/ajsr.2011.315.325

[3] Ahmed, H.O. \& Abdullah, A.A., Dust and respiratory symptoms among cement factory workers in the United Arab emirates. Industrial Health, 50, pp. 214-222, 2012. http://dx.doi.org/10.2486/indhealth.MS1320

[4] Schuhmacher, M., Nadal M. \& Domingo, J.L., Environmental monitoring of PCDD/ Fs and metal in the vicinity of a cement plant after using sewage sludge as a secondary fuel. Chemosphere, 7, pp. 1502-1508, 2009.

http://dx.doi.org/10.1016/j.chemosphere.2008.11.055

[5] Schuhmacher, M., Llobet, J.M., Granero, S., Rivera, J., Muller, L. \& Domingo, J.L., Atmospheric deposition of PCDD/Fs near an old municipal solid waste incinerator: level in soil and vegetation. Chemosphere, 40, pp. 593-600, 2002. http://dx.doi.org/10.1016/S0045-6535(99)00292-1

[6] Demir, T.A., Isikli, B., Urer, S.M., Berber, A., Akar, T., Canbek, M. \& Kalyoncu, C., Nickel exposure and its effects. Biometal, 18, pp. 7-13, 2005.

http://dx.doi.org/10.1007/s10534-004-1209-9

[7] Alikija, W., Iyawe, V.I., Jarikre, L.N. \& Chiwuzie, J.C., Ventilatory function of workers at Okpella cement factory in Nigeria. West African Journal of Medicine, 9(3), pp. 187-192, 1990.

[8] Ezenwa, A.O., A study of the prevalence of occupational diseases and the factors affecting their identification and reporting in Nigeria. Nigerian Medical Journal, 31, pp. 12-14, 1996.

[9] Madrid, L., Diaz-Barrientos, E. \& Madrid, F., Distribution of heavy metal contents of urban soils in parks of Seville. Chemosphere, 49, pp. 1301-1308, 2002.

http://dx.doi.org/10.1016/S0045-6535(02)00530-1 
[10] Abassi, M.N. \& Tufail, M., Health risks assessment for heavy elements suspended in dusty air along Murree Highway, Pakistan. American-Eurasian Journal of Agriculture and Environmental Sciences, 13(3), pp. 372-377, 2013.

[11] WHO (World Health organization)., Cadmium environmental health criteria, Geneva, 134, 1992.

[12] Lai, H-Y., Hseu, Z-Y., Chen, T-C., Chen, B-C., Guo, H-Y. \& Chen, Z-S., Health riskbased assessment and management of heavy metals-contaminated soil sites in Taiwan. International Journal of Environmental Research and Public Health, 7, pp. 3595-3614, 2010. http://dx.doi.org/10.3390/ijerph7103596

[13] Rovira, J., Mari, M., Schuhmacher, M., Nadal, M. \& Domingo, J.L., Monitoring environmental pollutants in the vicinity of a cement plant: A temporal study. Archives of Environmental Contamination and Toxicology, 60, pp. 372-384, 2011. http://dx.doi.org/10.1007/s00244-010-9628-9

[14] Potts, P.J., Thrope, O.W., Isaacs M.C. \& Wright, D.W., High-precision instrumental neutron-activation analysis of geological samples employing simultaneous counting with both planar and coaxial detectors. Chemical Geology, 48(1-4), pp. 145-155, 1985.

[15] Ehmann, W.D. \& Vance, D.E. Radiochemistry and Nuclear Methods of Analysis, John Wiley \& Sons: Lexington Kentucky Aiken, SC, pp. 45, 1991.

[16] USEPA (United States Environmental Protection Agency). "Soil Screening Guidance: Technical Background Document”. EPA/540/R-95/128. Office of Soild Waste and Emergency Response; 1996.

[17] Hu, Y., Bai, Z., Zhang, L., Wang, X., Zhang, L., Yu, Q. \& Zhu, T., Health risk assessment for traffic policemen exposed to Polycyclic Aromatic Hydrocarbons (PAHs) in Tianjin, China. Science of the Total Environmental. 382, pp. 240-250, 2007. http://dx.doi.org/10.1016/j.scitotenv.2007.04.038

[18] Zhang, N., Liu, J., Wang, Q. \& Liang Z., Health risk assessment of heavy metal exposure to street dust in the zinc smelting district, Northeast China. Science of the Total Environment, 408, pp. 726-733, 2010.

http://dx.doi.org/10.1016/j.scitotenv.2009.10.075

[19] Man, Y.B., Sun, X.L., Zhao, Y.G., Lopez, B.N., Chung, S.S., Wu, S.C., Cheung, K.C. \& Wong, M.H., Health risk assessment of abandoned agricultural soils based on heavy metal contents in Hong Kong, the world's most populated city. Environmental International, 36, pp. 570-576, 2010.

http://dx.doi.org/10.1016/j.envint.2010.04.014

[20] USEPA (United States EPA)., Supplement Guidance for developing soil screening level for superfund sites. OSWER 9355.4-24. Office of solid waste and Emergency Response, 2001.

[21] Li, P-H., Kong, S-F., Geng, C-M., Han, B., Lu, B., Sun, R-F., Zhao, R-J. \& Bai1, Z-P., Assessing the hazardous risks of vehicle inspection workers' exposure to particulate heavy metals in their work places. Aerosol and Air Quality Research, 13, 255-265, 2010.

[22] WHO (World Health Organization), Guidelines for air quality. WHO/SDE/OEH/0002, World Health Organization, Geneva, Switzerland, 2000. Internet address: available at http://www.who.Int/peh 
[23] Kumar, V., Ramachandran, T.V. \& Prasad, R., Natural radioactivity in Indian building materials and by-products. Journal of Radioanalytical and Nuclear Chemistry, 266(3), pp. 93-96, 2011.

[24] Ali-Khodja, H., Belaala, A., Demmane-Debbih, W., Habbas, B. \& Boumagoura, N., Air quality and deposition of trace elements in Didouche Mourad, Algeria. Environmental Monitoring and Assessment, 138, pp. 219-231, 2000.

http://dx.doi.org/10.1007/s10661-007-9792-1

[25] Oguntoke, O., Awanu, A.E. \& Harord, J., Impact of cement factory operations on air quality and human health in Ewekoro Local Government Area, South-Western Nigeria. International Journal Environmental Studies, 69(6), pp. 934-945, 2012. http://dx.doi.org/10.1080/00207233.2012.732751

[26] Khamparia, A., Chattergee, S.K. \& Sharma G.D., Assessment on effect of cement dust pollution on soil health. Journal of Environmental Research and Development, 7(1A), pp. 368-374, 2013.

[27] Tiwari, S., Arnold, R., Saxena, A., Mishra, R.M. \& Tiwari, S., Seasonal concentration of SPM, $\mathrm{SO}_{2}$ and $\mathrm{NO}_{\mathrm{x}}$ in the ambient air at various sampling sites of JK white cement plant gotan, (Rajasthan). International Journal of Pharmaceutical and Life Sciences, 5(4), pp. 3485-3496, 2014.

[28] Zeleke, Z.K., Moen, B.E. \& Bråtveit, M., Cement dust exposure and acute lung function: A cross shift study. BMC Pulmonary Medicine, 10(9), pp. 1-8, 2010. http://dx.doi.org/10.1186/1471-2466-10-19

[29] Banerjee, A.D.K., Heavy metal levels and solid phase speciation in street dusts of Delhi, India. Environmental Pollution, 123, pp. 95-105, 2003. http://dx.doi.org/10.1016/S0269-7491(02)00337-8

[30] Bhargava, A.K., Gupta, R., Bhargava, S. \& Paridhi, D., Effect of automobile exhaust on total N, P and heavy metals of road side sugarcane at district Saharanpur. Ad Plant Science, 16, 557-560, 2003. 